УДК $784+781.62$

\author{
Тетяна Вікторівна Самая, \\ кандидат мистецтвознаства, \\ Київська муніципальна академія \\ естрадного та циркового мистецтв, \\ Київ, Україна, \\ e-mail: samaya-t68@ukr.net, \\ ORCID: 0000-0002-1429-2951
}

\title{
ОСОБЛИВОСТІ МУЗИЧНОГО МЕТРОРИТМУ В ЕСТРАДНОМУ ВОКАЛЬНОМУ ВИКОНАВСТВІ
}

Анотація. У статті порушується питання специфіки музичного метроритму в професійній підготовці естрадного вокаліста. Пропонується дискурсивний аналіз поняття «метроритм»; визначаються проблемні зони вивчення теорії ритму в сучасному вокальному виконавстві та науковому естрадознавчому полі.

Однією 3 головних проблем вокальної естради залишається поверхневий підхід до вивчення основ музичного метроритму. Актуальність питання полягає в забезпеченні представників науково-педагогічної галузі конструктивними знаннями 3 означеної проблематики. Розглядається не тривіальне бачення ритміки 3 позиції факультативного матеріалу або основ ділення тривалості нот (ї чіткого відтворення), а пропозиція підготувати у естрадного вокаліста професійне мислення до вивчення художньо-естетичних принципів ритму.

В освітніх програмах вокально-естрадного напряму відзначається дефіцит науково-дослідних матеріалів вивчення ритмічної культури, на якій базуються джаз, рок і поп-музика. У статті уточнюються особливості термінології сучасного вокаліста (офф-біт, патерн, стомпінг, риф, скет, крунінг); 
аналізується поняття «драйв», його специфічна особливість як чинника емоційного стану виконавця.

Встановлено, що змістовне наповнення музичного ритму $€$ основним інструментом динамічного мислення вокаліста/музиканта, іншими словами, першоджерелом формування інтонаційно-динамічного способу вираження мелодичної і гармонічної структури сучасної виконавської техніки.

Визначено, що в професійній освіті естрадного вокаліста приділяється недостатньо уваги принципам ритмічної мови джазу як особливого виду музичної естетики та імпровізаційної складової музикування. Наводяться практичні приклади кореляції вокальної партії на основі метроритмічної інтерпретації.

У статті зосереджується увага на важливості поглибленого вивчення вокальної ритміки, оволодінні метроритмічними принципами та ритмоінтонаційними прийомами виконавської техніки, що належним чином збагачує та ефективно доповнює художньо-естетичний бік вокального мистецтва естради.

Ключові слова: естрадознавство, вокальне мистецтво естради, теорія ритму, музичний метроритм, джазова ритміка, сучасне виконавство, термінологія, драйв, скет, крунінг

Вступ. У сучасному суспільстві 3 його стрімким розвитком технологій, глобалізацією «виробництва музики» такі поняття як «ритм» і «час» усе більше стають математичним, шаблонним чинником і на сьогодні вимагають філософського переосмислення.

Початок XX ст. відзначився загальним підйомом великих відкриттів та створенням нових художніх форм в усіх видах мистецтва. Музична культура не залишилася осторонь. Поява джазу 3 його унікальною ритмо-інтонаційною структурою вплинула та визначила історичний шлях розвитку сучасної 
музики. Нове мислення полягає не лише у мелодико-гармонічній структурі, а головним чином відрізняється від ортодоксального мислення та сприйнятті метроритмічних структур, що й до сьогодні примушує нас постійно шукати ключі до розкодування цього феномену.

Постановка проблеми. У вітчизняній професійній освіті підхід до вивчення ритму на базі формування стильових норм та правил й досі залишається формальним, що не виходить за рамки елементарної теорії музики. Освітні програми 3 естрадного вокалу переважно будуються на методиці академічного співу, де не враховується нова специфіка: звукоформування, атаки звуку, голосова техніка - у відповідності до сучасної виконавської практики.

Аналіз останніх досліджень і публікацій. Однією 3 важливих проблем у вокальній естраді залишається глибоке вивчення основ музичного метроритму. Цим питанням грунтовно займалися прогресивні практики-методисти різних музичних спеціальностей: І. Бриль (фортепіано), В. Коробка (естрадний вокал), С. Макієвський (ритміка, drum set) та ін. Поповнити теоретичний аспект допоможуть дослідження музикознавців М. Аркадьєва, В. Брайніна, Е. Курта, Л. Мазеля, М. Райса, В. Сарджента, М. Харлапа, В. Холопової, С. Чащіної та ін., що розглядали метроритм не лише в контексті європейської музичної традиції, але й через призму філософських уявлень та етнічних розвідок.

Мета статті - означити проблемні зони вивчення поняття «метроритм» у науковому естрадознавчому полі, а також необхідність оснащення представників професійноосвітнього напряму ефективними знаннями щодо музичного метроритму.

Виклад основного матеріалу. Музикант, педагог i дослідник теорії ритму М. Аркадьєв зазначає, що програмою максимум $\epsilon$ «спроба змінити в деяких аспектах елементарну (тобто базову, фундаментальну) теорію музики. Упродовж 
півтора століть вона справляе непомітний вплив на музичну ментальність самих різних рівнв - від побутового музикування до самосвідомості великих артистів та теоретиків. Повторимо: у деяких пунктах, особливо в тому, що стосується ритму, елементарну теорію музики, 3 нашої точки зору, необхідно змінювати. Це корисно як для навчальних завдань, так і для чистоти й точності самої теорії»[2, с. 231]. Цієї ж думки дотримувався М. Харлап: «Метр, як він представляється теоретикам, у нотному написанні можна було б, ймовірно, висловити більш доцільним чином - якби самі теоретичні уявлення відповідали дійсності. При зверненні до музичної практики простота і самоочевидність шкільних понять про такт виявляється оманливою» $[9$, с. 52].

Спеціаліст 3 ритміки С. Макієвський у своїх дослідженнях зазначає, що музичний метр - це неакустична моторно-рухова функція нашого організму, організована мозком, коригує універсальну цілісність в одночасному сприйнятті динамічних, аудіальних i чуттєвих складових метроритмічних процесів для формування музичної виразності. Дослідник стверджує, що багатовекторну ритміку слід впроваджувати в нашу свідомість, робити своєрідним емоційним моторним навігатором, на базі якого і формуються такі психологічні категорії, як свінг, грув, що створюють особливий стан емоційного підйому - драйв, а не окремі ритмічні фрагменти [6].

Наведемо цікавий приклад сучасного хореографічного мистецтва, який красномовно свідчить про значення ритміки й метроритму у напрямі сценічних мистецтв. Молода балерина Катерина Салкіна, випускниця Київського хореографічного училища, в своєму телевізійному інтерв'ю говорила, як у 2002 р. була запрошена на роботу до колективу Mоріса Бежара. Артистку вразив неординарний підхід балетмейстера до занять ритмікою, що проходили у вигляді повноцінних уроків із професійним педагогом-барабанщиком за ударною установкою. 
Хоча М. Бежар i був у свій час прихильником системи «естетичної ритміки» Ф. Дельсарта, але вважав, що формування почуття ритму та цілісність мнемонічних образів танцівника можна отримати безпосередньо через прямий контакт із ударними інструментами, оскільки ритм - домінуюче начало музики. Саме тому театр танцю М. Бежара й досі залишається одним із провідних у світі хореографічного мистецтва.

Головні принципи формування ритмочасової структури в сучасній музиці беруть свої витоки від джазового напрямку. Сьогодні вже ніхто не стане заперечувати, що джаз - це особлива культура, що простимулювала розвиток року і попмузики. 3 позиції музичної естетики, дослідження основ джазу, i, відповідно «джазового мислення», - завдання складне й вимагає поглиблених методів дослідження. Як зазначав В. Єрохін, «Завдання дослідника основ джазового мислення вже само собою настільки складне, що навряд чи можна було б очікувати остаточного рішення від одного музикознавця <..> більше того, його вирішення i сьогодні залишається перспективою майбутнього» $[8$, с. 6$]$.

Через особливість побудови метроритмичної основи джазової музики, її контекст практичного втілення не доступний для багатьох академічних виконавців, про що зауважує В. Сарджент: «Джазовий музикант володіє надзвичайно розвиненою здатністю розрізняти акценти, вловлювати їх підпорядкованість, і це проявляється в усьому, що він грає (навіть у найповільніших джазових п’єсах). Його вміння розпізнавати дрібні компоненти метрики виявляється через пристрасть до всякого роду витончених прийомів синкопування, абсолютно чужих для європейської музики. Саме відсутність такої здатності у більшості європейських (класичних) музикантів, як мені здається, і пояснює той загальновідомий факт, що їх спроби грати джаз виявляються малопереконливими» [8, с. 68]. 
Але судження В.Сарджента свідчить про те, що в освітніх програмах музичних закладів академічного спрямування взагалі не розглядаються принципи ритмічної мови джазу, його метроритмичні та ритмоінтонаційні ознаки, специфіка джазової естетики й імпровізаційної складової музикування. У сучасному виконавстві насичення музичного ритму змістовністю $€$ основним інструментом динамічного мислення музиканта, першоджерелом формування інтонаційнодинамічного способу мелодійної і гармонійної структури, що на сьогодні вимагає філософського переосмислення. Іншими словами, там, де думка виконавця пов’язана з відчуттям плину часового континууму, слідує імпровізаційна можливість прикрасити його різноманіттям змісту ритмічної структури, не обмежуючись нотографічним записом.

Ми мимоволі відійшли від переживання нашою свідомістю категорії музичного часу, перемістившись у прості форми відчуття лише його статичного пульсу. Стародавні мислителі були ближче до розуміння часу. Аврелій Августін (354-430 рр.) так пропонував філософське осмислення категорій часу: «Хто стане заперечувати, що майбутнього ще немає? Але в душі $є$ очікування майбутнього. I хто стане заперечувати, що минулого вже немає? Але і досі $є$ в душі пам'ять про минуле. I хто стане заперечувати, що теперішнє позбавлене тривалості: воно проходить миттєво. Наша увага, однак, тривала, і вона переводить у небуття те, що з'явиться. Тривалий не майбутній час - його немає; тривале майбутнє це тривале очікування майбутнього <..> Увага ж моя зосереджена на цьому, через що переправляється майбутнє, щоб стати минулим. Те, що відбувається з цілої піснею, то відбувається і з кожної їі часткою і 3 кожним стилем; те саме відбувається і $з$ тривалою дією, часткою якого $є$, може бути, ця пісня ...» [1, с. 131].

У такому контексті доречно згадати висловлювання С. Макієвського про те, що ритміку в естрадній музиці слід розглядати набагато ширше, аніж розвинене почуття ритму: 
«Ритміка в музиці, в широкому сенсі слова, - це латентне (приховане) співвідношення одночасності сполучених між собою метроритмічної архітектоніки і психологічних відчуттів, де кожна сторона наділена індивідуальними якостями. Елементарна форма цього процесу - коли при виконанні музичного твору музикант утримує відразу дві лінії часових потоків: одну - статичну (метричний пульс) і другу - динамічну (емоційну, психологічну). Найголовніше - не змішувати сутності цих двох структур і не робити поспішних висновків щодо здатності розрізняти їх і керувати ними» [7, с. 30].

Важливим комунікативним інструментом у формуванні якісного виконавського рівня сучасного музиканта/вокаліста залишається понятійна єдність термінології, зокрема таких термінів, як «офф-біт», «патерн», «стомпінг», які варто означити.

Oфpb-бim (off beat - від англ. «від біту») у широкому сенсі - особливий тип джазової ритміки, заснований на відхиленні ритмічних акцентів від чітко вибудуваних дольових пропорцій такту, а також «структурної синкопи». У вузькому розумінні цим терміном позначають перенесення акценту 3 сильних долей такту на слабкі. Термін «патерн» (pattern - від англ. «модель, малюнок») використовується для позначення остинатно повторюваних формул-моделей: ритмічних, мелодичних, фактурних, акцентних, гармонічних та ін. [8].

Cтомпінг (stomping - від англ. «топтання на місці»), за визначенням В. Сарджента - «техніка остинато, пов'язана 3 використанням паттернів як засобів динамічного нагнітання та посилення внутрішнього динамічного конфлікту» [8, с. 244], $p u \phi$ - різновид мелодичного стомпу, характерний для стилю «свінг». До виконавських метроритмічних прийомів належать засоби виразності, запозичені 3 академічної музики: такm вищого порядку (групування простих тактів в один «великий такт»), геміола (поліметричний прийом, створений на бінарних 
ритмічних фразах у складі тріольних фігур), агогіка (відхилення від статичного темпу й ритму).

Працюючи над музичним твором, виконавець завжди має враховувати багатовекторність ритмічних пластів, де присутні статичний ритм - метрична пульсація твору, й ритм динамічний - основа життя музичного твору, вираження найтонших часових відтінків, підсвідомо узгоджених із нашими емоціями. Такі часові кореляції створюються за допомогою різних засобів чуттєвої виразності: агогіки, динаміки, нюансування й акцентуації. Завдяки опануванню інструментарієм художнього ритмоутворення виконавець може наблизитися до розкриття мнемонічною образності ритмічного викладу, динаміки його прихованих структур, конфлікту i взаємодії образів. Це впливає на акустичний план і функціонує як чинник індивідуального бачення латентної структури, створеної на ментальному рівні. Віртуальні ритмічні потоки в емоційній уяві забезпечують фантастичну гнучкість музичної композиції, витонченість і реальний фізичний вплив на психіку слухача, - те, що в сучасному музичному середовищі називається драйвом.

Володіючи знаннями про механізми психологічного впливу на публіку, що будуються на метроритмічних поєднаннях, досвідчений виконавець здатен управляти не лише своїми емоціями, а й почуттями слухача. М. Аркадьєв зазначає: «Насправді категорія часу досить проблематична, та іiі вивчення можливо, судячи з усього, лише тоді, коли дослідник встановить для себе значення цього звичного слова, поставить для себе систему аксіом, у межах якої йому доведеться працювати» [2, c. 9].

У вітчизняних ЗВО естрадно-джазового напряму освітні програми вивчення музичної ритміки переважно апагогічні, далекі від предмету дослідження. В результаті чого виконавському мистецтву даного профілю не вистачає знань тих елементів ритмічної культури, на яких базуються джаз, рок i 
поп-музика. Тому емоційно-психологічне почуття драйву в них частіше стихійне, оказіональне, аніж усвідомлене.

Поява великої кількості приватних студій естрадного вокалу, що базуються на авторських методах викладачів 3 емпіричним досвідом роботи, спричинило вільне трактування професійних термінів. Розглянемо це на прикладі терміну «драйв». Творча молодь трактує його переважно у формі куражу, жаргонізму, маючи на увазі викид експансивної енергії, скажімо, в рок-музиці (екстрім-вокал).

Вірогідно, 3 тієї ж причини в сучасних наукових дослідженнях термін «драйв» тлумачиться некоректно. Таким прикладом може бути дисертація О. Бойка «Українська масова музика: етапи розвитку, національні особливості», де автор пише, що драйв «використовується для характеристики ритмічних особливостей джаз-, рок- або похідних від цих видів акомпанементу, в якому послідовно виконувані метричні одиниці, елементи пульсації тощо в однаковій мірі підкреслюються темброво, динамікою або іншою формою виразності. Ритм драйву не співпадає зі встановленим ритмічним малюнком i через багаторазові повторювання сприймається як рушійна сила або спрямованість музичного твору. Щодо виконавства термін «драйв» також включає в себе моменти, коли музикант розтягує, прискорює, інтерсифікує або іншим способом «грає» з ритмом» [3, с. 206].

Відзначимо, що сутність такого явища як драйв не може базуватися на динамічній складовій ритмоструктури, тим більше, на ітеративних діях, у професійній лексиці це визначається як риф або патерн. Відносно висловлювання О. Бойка щодо моментів, «коли музикант розтягує, прискорює, інтерсіфікує або іншим способом «грає» 3 ритмом» - не стосується драйву, а належить до агогіки.

Драйв створюється поєднанням метроритмічних взаємодій бінарних і тернарних структур (особливо у свінгу), що на тонкому рівні формує чуттєві сигнали психіки як результат 
впливу синкопованої ритміки, офф-біту, поліритмії паралельних симультанних ритмів. Іншими словами, відчуття драйву музикант здатен сформувати не лише в джазі, але і в рокта поп-музиці.

Важливу складову естетики джазового стилю формує i «латентна ритміка», що в професійній лексиці визначає сприйняття нашими органами чуття музично-часового компоненту на ментальному рівні. Цей особливий елемент емоційного стану виконавця є збудником виникнення драйву, не фіксується нотним текстом, лежить в імпровізаційній площині, що базується на метроритмічному конфлікті.

Драйв не належить до засобів музичної виразності або до художньо-естетичних явищ, він має відношення до похідної одиниці емоційного підйому як екстатичного чинника. Це результат метроритмічної «гри» між статичними й динамічними часовими потоками, які конфліктують між собою, доповнюючи чуттєві контрасти. Всі часові компоненти об'єднуються загальними динамічними характеристиками саунду просторово-звукового образу виконавця, який психологічно впливає на підготовленого слухача, викликаючи відповідні реакції i називають терміном «драйв». Зазвичай, непідготовлений слухач не в змозі відчути драйв незнайомою для нього музичною мовою (жанру, стилю), т. зв. «слухового кругозору».

Як підтвердження вищевказаного, можна згадати випадок, що описує В. Коробка у своїй праці «Вокал в популярній музиці» [5]. Згадується випадок, який стався під час гастролей у Москві всесвітньо відомого джазового піаніста Ч. Коріа та вібрафоніста Г. Бертона на сейшні в Спілці композиторів. Упродовж усього виступу Чік Коріа був змушений грати на барабанах, а не на фортепіано, оскільки серед присутніх музикантів не знайшлося такого барабанщика, який би зміг задати необхідної свінгової пульсації для гри в ансамблі. Адже саме відповідна пульсація має психологічний 
вплив на джазового музиканта й асоціюється 3 динамічною медитацією на ментальному рівні.

Якими засобами виразності створюється драйв у підготовленого виконавця, і що залишається поза увагою у початківця?

У класичній традиції ритмічна послідовність нотного тексту вокальної партії еталонізована й наближена до статичного відтворення музичної тканини. Саме про це Б. Іоффе писав, що існує «проблема навчання музики, яка поширена у вищих навчальних закладах. Там панує міф «вірності тексту», причому в основному мається на увазі, власне, його поверхневий пласт, не далі аніж того, що видно на нотній «картинці». Як правило, молоді виконавці не задаються питаннями, пов'язаними 3 інтерпретацією тих шедеврів, що грають, ніби всі ці питання вже давно вирішені «вищими авторитетами» <..> У результаті їх виконання справляє враження «мертвої букви», на зразок ситуації, коли актор красивим, поставленим голосом голосно і чітко читає текст незнайомою для нього мовою» [4, с. 3].

Іншу картину ми бачимо у джазового виконавця, для якого графічна нотація партії частіше представлена лише ескізом, замальовкою звучить композиції (рис. 1-2).

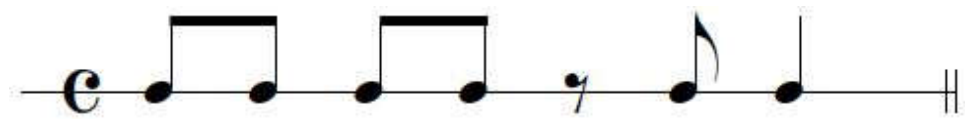

Рис. 1. Фрагмент ритму нотної партії

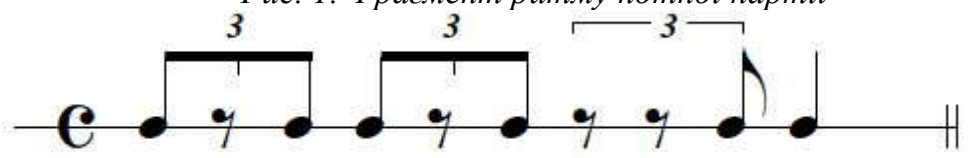

Рис. 2. Його практичне виконання

Така форма знайома кожному джазовому музиканту/вокалісту, чия мнемонічна образність відбувається 
через індивідуальне осмислення ритмічної інтерпретації, в основі якої лежить не розшифровка нотних позначень, а фактура стилю, - підсвідоме втілення в одночасності бінарного i тернарного континуумів, характерних для джазової ритміки.

Особливістю джазового вокалу $\epsilon$ те, що у своїх імпровізаціях соліст імітуе звучання духового інструменту оркестру (прийоми субтон, гроул). Силабічний прийом виспівування музичного тексту не належать до жодної мови світу й визначається як «інструментальний вокал», а сама вокальна імпровізація отримала назву «скет» (від англ. «scat»). Нагадаємо, що засновником скет-вокалу $є$ американський джазовий трубач і співак Л. Армстронг.

Застосування скету можна розглянути на прикладві творчості французького вокального гурту початку 60-х рр. XX ст. «The Swingle Singers» [11]. Це один із перших вокальних колективів, що виконував класичну музику в свінговій манері. Перший досвід такої роботи був використаний гуртом у створенні вокальної версії «Добре темперованого клавіру» Й. С. Баха. Дебютний альбом називався «Джаз Себастьян Бах» («Jazz Sebastian Bach», 1963 р.) і приніс ансамблю світову славу та першу премію «Греммі». Ця унікальна робота багато в чому продемонструвала сутність побудови джазової вокальної стилістики, де без зміни авторського тексту виконавці своєю майстерністю переносять музику в іншу епоху. Така трансформація виявилася цілком виправданою і досконалою, а їх альбом і сьогодні входить у сотню кращих альбомів світу.

Якщо порівнювати виконання академічними музикантами тих самих композицій Й. С. Баха, що ми чуємо у «The Swingle Singers», то їх звучання завжди близьке до ідеально витриманого часу, зафіксованого в нотному тексті. При виконанні їх джазових інтерпретацій співаки отримують зовсім іншу естетику звучання, освінгованну. Нотний запис для джазового музиканта $\epsilon$ лише нарисом композиції, в якому ладовисотна складова може зберігатися цілком або частково, але 
ритмоінтонаційний компонент завжди поступається місцем емоційному чиннику, відповідно до джазової естетики виконання.

В епоху свінгу з'явилася ціла плеяда співаків-крунерів із м'якою манерою співу з використанням освінгованної ритміки, цей напрям отримав назву «крунінг» (муркотіння). Надалі його яскравими представниками стали Бінг Кросбі, Нет Кінг Коул, Френк Сінатра, Перрі Комо, Енді Вільямс, Дін Мартін, Тоні Беннетт, Майкл Бублей та ін.

Завдання співака-крунера полягало у знаходженні балансу між свінговою традицією і власною інтерпретацією, де елементи інтонації, мелодичні побудови, зіставлення, музичні образи стають його творчим матеріалом. Проте головною ознакою крунерського виконання було постійне використання солістом alla-breve (2/2) в основному акомпонементі оркестру в розмірі 4/4. У такій манері «легкого» шаффл-ритму 3 впровадженням метроритмічного прийому такту вищсого порядку спів робився польотним, вільним, «необтяженим» статичним метром титульного розміру.

Проіллюструємо це відомим твором 1960-70-х рp. «Somos novios» («It's impossible») Армандо Монсанеро у виконанні Андреа Бочеллі і Перрі Комо. Кожен із цих співаків досконало володіє своїм виконавським мистецтвом i представляє свій вокальний напрям естрадної музики.

Для прихильників класичного кросоверу виконання А. Бочеллі створить атмосферу естетичного переживання, наближену до академічної традиції, де співак ритмічно дотримується титульного розміру, користуючись агогікою як основою художньої виразності [10]. У другому прикладі співаккрунер П. Комо, користуючись ритмоінтонаційними та метроритмічними прийомами, збагачує палітру психологічного сприйняття твору через власну інтерпретацію відповідно до свого стилю [12]. 
Відмінність існуе i у стосунках із оркестром: у класичному кросовері виконавські функції розділені на соліста та акомпанемент, а у крунінгу - це партнерська взаємодія. Версія «It's impossible» П. Комо на адаптований англійський текст Сіда Уейна у 1971 р. була удостоєна премії «Греммі» [13].

Джазова ритміка формується на основі латентно протікаючих метроритмічних послідовностей, які не визначаються межами тактового розміру й чіткою математичної систематизацією ритмоінтонаційних структур. На прикладі П. Комо можна переконатися, що, використовуючи симультанне співвідношення ритмів, виконавець частково спирається на статичні дольові цикли, оскільки у кожного метра, що паралельно протікає, є свій дольовий контур. Тому музикант не вираховує співвідношення часових інтервалів, а навмисно лавірує між ними, не вибудовує пріоритети, а створює мнемонічний образ метричної пульсації.

Таким чином, для посилення метричного конфлікту естрадний вокаліст інтуїтивно вибирає напрацьовані технічні шаблони й патерни, через взаємодію метроритмічних поєднань. Він використовує організацію такту вищого порядку, риф, стомп-патерн, геміолу, агогіку - всі ті ритмічні засоби виразності, які підсилюють конфлікт, драматургію психологічного сприйняття вокального твору 3 подальшою розрядкою, релаксацією процесу напруженості.

Висновки. У вокальному мистецтві естради необхідність вирішення проблем ритміки як важливого компоненту підтверджує той факт, що емоції нашої національної ментальності пов'язані з мелодикою і переважають над ритмом, не поступаючись розумному збагаченню художньоестетичним розмаїттям метроритмічної палітри. Як правило, якісне створення образу композиції без «незбагачення» емоційним запалом, не отримує розвитку й завершеності через тривіальне мислення молодого артиста, отже, приречене на коротке життя. 
У сучасному вокальному виконавстві особливе значення мають прийоми роботи 3 музичним метроритмом, що $\epsilon$ основним інструментом інтонаційно-динамічної передачі мелодичної та гармонічної структури твору. У вокальній естраді метроритм виконує функцію першооснови формування симультанних ритмів, які забезпечують емоційний підйом та створення повноцінного сценічного образу.

Проблемні зони розвитку музичної ритміки й сьогодні залишаються вкрай важливими в освітніх програмах виховання професійного естрадного вокаліста. Поглиблене вивчення теорії ритму, знання метроритмічних принципів виконавської техніки співака мають збагатити творчу ерудицію, сприяти розвитку професійної мови, через яку надається унікальна можливість розкрити й ефективно доповнити художньо-естетичну сторону вокального мистецтва естради.

\section{Література}

1. Августин Аврелий. Исповедь блаженного Августина, епископа Гиппонского. Москва: АСТ, 2003. 440 с.

2. Аркадьев М. Фундаментальные проблемы музыкального ритма и «незвучащее». Время, метр, нотный текст, артикуляция. Saarbrücken: Lap Lambert Academic Publishing, 2012. 408 c.

3. Бойко О. Українська масова музика: етапи розвитку, національні особливості: дис. на здобуття наук. ступеня канд. мистецтвознав. Київ, 2017. 215 с.

4. Иоффе Б. О вреде нотного письма. URL: http://www.docme.ru /doc/1695901/ ioffe-b.-o-vrede-notnogo-pis._ma

5. Коробка В. Вокал в популярной музыке. Москва: Типография п/о «ВААП-ИНФОРМ», 1989. 46 с.

6. Макиевский С. О ритмике и метроритме. URL:http://www.drumspeech.com/topic.php?forum=teachers2\&the me_id=29128

7. Макиевский С. Ритмика для всех. Санкт-Петербург: Композитор, 2011. 104 с. 
8. Сарджент У. Джаз: Генезис. Музыкальный язык. Эстетика. Москва: Музыка, 1987. 296 с.

9. Харлап М. Тактовая система музыкальной ритмики. Проблемы музыкального ритма. Москва: Музыка, 1978. С. 48104.

10. Andrea Bocelli. Somos Novios. Live From Castagneto Carducci, Italy. 2001. URL: https://www.youtube.com/watch?v=Qq0I0x_U-g 11. Cunniffe, Thomas. The swingle singers: making the music dance. URL: https://jazzhistoryonline.com/swingle-singers
12. Perry
Como.
It's
Impossible.
URL:

https://www.youtube.com/watch?v=BKQ9--_ZgB4\&list=RDBKQ9-

-_ZgB4\&start_radio $=1 \& \mathrm{t}=5$

13. Somos Novios (It's Impossible). URL: https://en.wikipedia.org/wiki/Somos_Novios_(It\%27s_Impossible)

\section{Татьяна Викторовна Самая,}

кандидат искусствоведения,

Киевская муниципальная академия

эстрадного и циркового искусств,

Киев, Украина, e-mail: samaya-t68@ukr.net,

ORCID: 0000-0002-1429-2951

\section{ОСОБЕННОСТИ МУЗЫКАЛЬНОГО МЕТРОРИТМА В ЭСТРАДНОМ ВОКАЛЬНОМ ИСПОЛНИТЕЛЬСТВЕ}

Аннотация. В статье поднимаются вопросы специфики музыкального метроритма в профессиональной педагогической подготовке эстрадного вокалиста. Предлагается дискурсивный анализ понятия «метроритм», определяются проблемные области изучения теории ритма в современном вокальном исполнительстве и научном эстрадоведческом поле. 
Одной из основных проблем вокальной эстрады остается поверхностный подход к изучению основ музыкального метроритма. Актуальность вопроса заключается в обеспечении представителей научно-педагогического направления конструктивными знаниями по указанной проблематике. Рассматривается не тривиальное видение ритмики, с позиции факультативного материала или основ деления длительностей нот (их чёткого воспроизведения), а предложение подготовить у эстрадного вокалиста профессиональное мышление к изучению художественно-эстетических принципов ритма.

В образовательных программах вокально-эстрадного направления ощущается дефицит научно-исследовательских материалов изучения ритмической культуры, на которой базируются джаз, рок и поп-музыка. В работе уточняются особенности терминологии современного вокалиста (офф-бит, паттерн, стомпинг, рифф, скэт, крунинг), анализируется понятие «драйв», его специфическая особенность как фактора эмоционального состояния исполнителя.

Установлено, что в современной исполнительской технике содержательное наполнение музыкального ритма является основным инструментом динамического мышления вокалиста/музыканта, точнее сказать, первоисточником формирования интонационно-динамического способа выражения мелодической и гармонической структуры.

Определено, что в профессиональном образовании эстрадного вокалиста недостаточно уделяется внимания принципам ритмического языка джаза как особого вида музыкальной эстетики и импровизационной составляющей музицирования. Приводятся практические примеры корреляции вокальной партии на основе метроритмической интерпретации.

В статье концентрируется внимание на важности углубленного изучения вокальной ритмики, овладении метроритмическими принципами и ритмоинтонационными приёмами исполнительской техники, что должным образом 
обогащает и эффективно дополняет художественноэстетическую сторону вокального искусства эстрады.

Ключевые слова: эстрадоведение, вокальное искусство эстрады, теория ритма, музыкальный метроритм, джазовая ритмика, современное исполнительство, терминология, драйв, скэт, крунинг

\title{
Tetyana V. Samaya,
}

$\mathrm{PhD}$ in Arts,

Kyiv Municipal Academy of Circus and Variety Arts,

Kyiv, Ukraine, e-mail: samaya-t68@ukr.net,

ORCID: 0000-0002-1429-2951

\section{FEATURES OF THE MUSICAL METRORITHM IN VARIETY VOCAL PERFORMANCE}

\begin{abstract}
The article raises questions of the specifics of the musical metrorhythm in the professional pedagogical training of a variety vocalist. A discourse analysis of the concept of "metrorhythm" is offered; the problem areas of the study of the musical metrorhythm in the scientific field of estradology are determined.

One of the main problems of the variety vocal is a deep study of the foundations of the musical metrorhythm. The relevance of the issue lies in providing the representatives of the scientific and pedagogical direction with constructive knowledge on the indicated problems. The article considers not a trivial approach to the study of rhythm, from the standpoint of optional material or the basics of dividing note durations and their clear reproduction, but a proposal to prepare professional thinking for the study of artistic and aesthetic principles of rhythm in a variety vocalist.

In the educational programs of the variety-vocal direction, there is a shortage of research materials for studying the rhythmic
\end{abstract}


culture on which jazz, rock and pop music are based. The study clarifies the features of the terminology of a modern vocalist (offbeat, pattern, stomping, riff, scat, crooning); the definition of the concept «drive», its specific features as a factor of the emotional state is given.

It has been established that in modern performing techniques, the content of the musical rhythm is the main instrument of the vocalist/musician's, dynamic thinking, the primary source of the formation of the intonational-dynamic way of expressing the melodic and harmonic structure. It is determined that in the professional education of a variety vocalist, not enough attention is paid to the principles of the rhythmic language of jazz as a special type of musical aesthetics and the improvisational component of music making. Practical examples of vocal part correlation based on metrorhythmic interpretation are given.

The article focuses on the importance of an in-depth study of vocal rhythm, mastering the metrorhythmic principles of performing technique, which properly enriches and effectively complements the artistic and aesthetic side of vocal variety art.

Key words: estradology, vocal variety art, theory of rhythm, musical metrorhythm, jazz rhythmic, contemporary performance, terminology, drive, scat, crooning

\section{References}

1. Avgustin Avrelij (2003). Ispoved blazhennogo Avgustina, episkopa Gipponskogo [Confession of blessed Augustine, bishop of Hipponsky]. Moscow: AST, [in Russian].

2. Arkadiev, M. (2012). Fundamentalnye problemy muzykalnogo ritma i «nezvuchashee». Vremya, metr, notnyj tekst, artikulyaciya [Fundamental problems of musical rhythm and "unsounding". Time, meter, musical text, articulation]. Saarbrücken: Lap Lambert Academic Publishing [in Russian].

3. Bojko, O. (2017). Ukrayinska masova muzika: etapi rozvitku, nacionalni osoblivosti [Ukrainian mass music: stages of 
development, national features]: dis. na zdobuttya nauk. stupenya kand. mistectvoznav. Kyiv [in Ukrainian].

4. Ioffe, B. O vrede notnogo pisma [About the dangers of musical notation]. Available at: http://www.docme.ru /doc/1695901/ ioffe-b.-o-vrede-notnogo-pis._ma [in Russian].

5. Korobka, V. (1989). Vokal v populyarnoj muzyke [Vocal in popular music]. Moscow: Tipografiya p/o "VAAP-INFORM" [in Russian].

6. Makievskij, S. O ritmike i metroritme [About rhythm and metrorhythm].

http://www.drumspeech.com/topic.php?forum=teachers2\&theme id=29128 [in Russian].

7. Makievskij, S. (2011). Ritmika dlya vseh [Rhythm for everyone]. Sainct-Petersburg: Kompozitor [in Russian].

8. Sardzhent, W. (1987). Dzhaz: Genezis. Muzykalnyj yazyk. Estetika [Jazz: Genesis. Musical language. Aesthetics]. Moscow: Muzyka [in Russian].

9. Harlap, M. (1978). Taktovaya sistema muzykalnoj ritmiki [System of takta in music rhythmica]. Problemy muzykalnogo ritma. Moscow: Muzyka, 48-104 [in Russian].

10. Andrea Bocelli (2001). Somos Novios. Live From Castagneto Carducci, Italy. Available at: https://www.youtube.com/watch?v=Qq0I0x_U-g [in English].

11. Cunniffe, Thomas. The swingle singers: making the music dance. Available at: https://jazzhistoryonline.com/swingle-singers [in English].

12. Perry Como. It's Impossible. Available at: https://www.youtube.com/watch?v=BKQ9--_ZgB4\&list=RDBKQ9-_ZgB4\&start_radio=1\&t=5 [in English].

13. Somos Novios (It's Impossible). Available at: https://en.wikipedia.org/wiki/ Somos_Novios_(It\%27s_Impossible) [in English]. 